\section{First cytochemical study of haemocytes from the crab Carcinus aestuarii (Crustacea, Decapoda)}

\author{
V. Matozzo, M.G. Marin \\ Department of Biology, University of \\ Padova, Italy
}

\section{Abstract}

For the first time, a morphological study of haemocytes from the crab Carcinus aestuarii was carried out by means of light microscopy and differing cytochemical assays. Analysis of haemocyte size frequency distribution (performed by means of a Coulter Counter) revealed the presence of two distinct haemocyte fractions in $C$. aestuarii haemolymph, depending on cell size. The first fraction was of about 3-5 $\mu \mathrm{m}$ in diameter and 30-50 fL in volume, the second was of about 6-12 $\mu \mathrm{m}$ in diameter and over $200 \mathrm{fL}$ in volume. Mean cell diameter and volume were $8.20 \pm 1.7 \mu \mathrm{m}$ and $272.30 \pm 143.5 \mathrm{fL}$, respectively. Haemocytes observed under light microscope were distinguished in three cell types: granulocytes (28\%; $11.94 \pm 1.43 \mu \mathrm{m}$ in diameter) with evident cytoplasmic granules, semigranulocytes $(27 \%$; $12.38 \pm 1.76 \mu \mathrm{m}$ in diameter) with less granules than granulocytes, and hyalinocytes $(44 \%$; $7.88 \pm 1.6 \mu \mathrm{m}$ in diameter) without granules. In addition, a peculiar cell type was occasionally found (about 1\%): it was 25-30 $\mu$ m in diameter and had a great vacuole and a peripheral cytoplasm with granules. Granulocyte and semigranulocyte granules stained in vivo with Neutral Red, indicating that they were lysosomes. Giemsa's dye confirmed that granulocytes and semigranulocytes were larger than hyalinocytes. Pappenheim's panoptical staining and Ehrlich's triacid mixture allowed to distinguish granule-containing cells (including semigranulocytes) in acidophils (64\%), basophils (35\%) and neutrophils (1\%). Hyalinocytes showed always a basophilic cytoplasm. Haemocytes were positive to the PAS reaction for carbohydrates, even if cytoplasm carbohydrate distribution varied among cell types. Lastly, lipids were found on cell membrane and in cytoplasm of all haemocyte types in the form of black spots produced after Sudan Black B staining. The morphological characterisation of $C$. aestuarii haemocytes by light microscopy was necessary before performing both ultrastructural and functional studies of circulating cells.

\section{Introduction}

Like other arthropods, Crustacea have an open vascular system in which numerous haemocytes freely circulate in haemolymph. Crustacean haemocytes are involved in important functions, such as wound repair and defence mechanisms against parasites, viruses and bacteria. ${ }^{1}$ In many crustacean species, haemocytes originate from a specialised haematopoietic tissue generally situated on the dorsal and dorsolateral sides of the stomach and surrounded by connective tissue. Cells, perhaps haematopoietic cells, are packed in small lobules, and some of these cells are also found in the interlobular spaces. ${ }^{2}$ Although the haematopoietic tissue has been identified in some crustacean species, such as Carcinus maenas, Homarus americanus, Pacifastacus leniusculus, and Penaeus monodon,,$^{3-6}$ the relationship between haematopoietic tissue cells and circulating haemocytes is still unclear.

Classification of crustacean haemocytes has been (and still is) one of the most debated point, mostly due to the lack of uniform classification criteria that enable to distinguish cell types. ${ }^{1,2}$ Classification schemes are different for each species and are based on either haemocyte cytochemical properties, morphological aspect, biological functions or observation techniques. Therefore, resulting nomenclature is often controversial. Hose et al. ${ }^{7}$ and Gargioni and Barracco ${ }^{8}$ proposed to combine morphological, cytochemical and functional features of the crustacean haemocytes for a more convenient classification. In most of the Crustacea species, haemocyte classification is generally based on the presence/absence of cytoplasmic granules. Following this criterion, three types of circulating haemocytes are usually recognised in Crustacea: hyalinocytes (the smallest cells without evident granules), semigranulocytes (containing small granules) and granulocytes (with abundant cytoplasmic granules) (see Bauchau ${ }^{1}$ for a review). However, other synonymous terms were proposed in the past to indicate these cell types. For example, granulocytes were also defined as granular eosinophils ${ }^{9}$ or granular amoebocytes,${ }^{10}$ semigranulocytes were indicated as monocytes ${ }^{11}$ or intermediate cells ${ }^{12}$ and hyalinocytes were also termed phagocytes ${ }^{13}$ or pro-haemocytes. ${ }^{14}$ Johnston et al..$^{15}$ classified Carcinus maenas haemocytes in two types ( $\alpha$ and $\beta$-cells), whereas William and Lutz ${ }^{16}$ divided the haemocytes from the same crab species in two types, on the basis of the presence/absence of glycogen-containing granules. In the Indian spiny lobster, Panulirus homarus, Manjula et al. ${ }^{17}$ observed four types of haemocytes (pro-hyalocytes, hyalocytes, eosinophilic granulocytes and chromophilic granu-
Correspondence: Valerio Matozzo, Department of Biology, University of Padova, via Ugo Bassi, 58/B, 35131 Padova, Italy.

Tel.: +39.049.8276201 - Fax: +39.049.8276199. E-mail: matozzo@bio.unipd.it

Key words: Carcinus aestuarii, crab, haemocytes, light microscopy, cytochemical assays, morphological characterisation.

Received for publication: 1 December 2009. Accepted for publication: 14 January 2010.

This work is licensed under a Creative Commons Attribution 3.0 License (by-nc 3.0).

(C) Copyright V. Matozzo and M.G. Marin 2010 Licensee PAGEPress, Italy

European Journal of Histochemistry 2010; 54:e9 doi:10.4081/ejh.2010.e9

locytes), whereas in the blue crab, Callinectes sapidus, three types of haemocytes - hyaline cells, small and large granulocytes - were identified by Clare and Lumb. ${ }^{18}$ Surprisingly, eleven haemocyte types were recently described in the American lobster, $H$. americanus, using morphological criteria. ${ }^{19}$

To our knowledge, no study concerning morphological characterisation of circulating haemocytes from the crab Carcinus aestuarii has previously been performed. As a consequence, the aim of the present study was to examine crab haemocytes under light microscope and classify them by means of various cytochemical assays, prior to perform both ultrastructural and functional studies of haemocytes.

\section{Materials and Methods}

\section{Animals}

Intermoult adult males of $C$. aestuarii $(4 \mathrm{~cm}$ mean carapace length) were collected by handmade traps in the lagoon of Venice, kept in the laboratory in large aquaria provided with a sandy bottom, in seawater at salinity of $35 \pm 1 \%$, at a temperature of $17 \pm 0.5^{\circ} \mathrm{C}$, and fed with mussels (Mytilus galloprovincialis). The crabs were acclimatised in the laboratory for 5 days before analyses.

\section{Haemolymph sampling}

Crabs were anaesthetised on ice for $10 \mathrm{~min}$, and the haemolymph (at least $250 \mu \mathrm{L} / \mathrm{crab}$ ) was collected from the unsclerotised membrane of the walking legs using a 1-mL plastic syringe, placed in Eppendorf tubes and diluted $1: 2$ in an anticoagulant solution of citrate buffer/EDTA (NaCl $0.45 \mathrm{M}$, glucose $0.1 \mathrm{M}$, sodi- 
um citrate $30 \mathrm{mM}$, citric acid $26 \mathrm{mM}$, EDTA 10 $\mathrm{mM}, \mathrm{pH} 4.6$ ) stored at $4^{\circ} \mathrm{C} .^{20}$

\section{Haemocyte size frequency distribution}

Haemocyte size frequency distribution was determined immediately after haemolymph sampling by a Model Z2 Coulter Counter electronic particle counter/size analyser (Coulter Corporation, FL, USA) ${ }^{21}$ Briefly, $125 \mu \mathrm{L}$ of haemolymph from 10 individual crabs were added to $19.875 \mathrm{~mL}$ of $0.45 \mu \mathrm{m}$ filtered seawater (FSW). Anticoagulant or fixative solutions were omitted. Mean cell diameter and volume were measured and expressed as $\mu \mathrm{m}$ and femtolitres (fL), respectively.

\section{Short-term haemocyte cultures and in vivo observation of haemocyte}

Pools of haemolymph (from 2 crabs each) were used to prepare short-term haemocyte cultures. Pooled haemolymph was then centrifuged at $780 \times \mathrm{g}$ for $10 \mathrm{~min}$, the supernatant was discarded, and haemocytes were resuspended in an equal volume of FSW. Short-term haemocyte cultures were prepared according to Ballarin et al. ${ }^{22}: 60 \mu \mathrm{L}$ of haemocyte suspensions were placed in the middle of culture chambers made by glueing Teflon rings (15 $\mathrm{mm}$ internal diameter, $1 \mathrm{~mm}$ thickness) on glass slides; a small amount of vaseline was put on the rings surface to allow adhesion of the coverslips. The culture chambers were then kept upside down for $30 \mathrm{~min}$ at room temperature to allow adhesion of the haemocytes to the coverslips. For in vivo observation, haemocytes were not fixed. The diameter of each haemocyte type was measured in 100 cells by means of an image analysis software (see below for details). Cell diameter was measured in unfixed haemocytes to avoid shrinkage due to fixation.

\section{Cytochemical assays}

Except for the in vivo Neutral Red assay, haemocyte monolayers were fixed for $30 \mathrm{~min}$ at $4^{\circ} \mathrm{C}$ in a solution of $1 \%$ glutaraldehyde (Fluka) in FSW containing 1\% sucrose. They were then washed in phosphate buffered saline, pH 7.2, (PBS: $1.37 \mathrm{M} \mathrm{NaCl}, 0.03 \mathrm{M} \mathrm{KCl}$, $0.015 \mathrm{M} \mathrm{KH}_{2} \mathrm{PO}_{4}, 0.065 \mathrm{M} \mathrm{Na}_{2} \mathrm{HPO}_{4}$ ) and stained according to various cytochemical methods in order to identify haemocyte types. Slides were mounted in Acquovitrex (Carlo Erba, Milan, Italy) and observed under a light microscope. The following cytochemical staining methods were used:

i) Neutral Red dye. After haemocyte adhesion to the coverslips, FSW was removed from the culture chambers and substituted with $60 \mu \mathrm{L}$ of a $8 \mathrm{mg} / \mathrm{L}$ Neutral Red (Merck) solution in
FSW. Haemocytes were then observed in vivo, and lysosomes appeared red.

ii) Giemsa's dye. Haemocytes were stained for $10 \mathrm{~min}$ in a $10 \%$ Giemsa (Fluka) aqueous solution, washed in distilled water and then mounted. Nuclei appeared blue and cytoplasm pale blue or violet.

iii) Pappenheim's panoptical staining. Haemocytes were stained for $3 \mathrm{~min}$ in MayGrünwald's dye (Fluka). After washing in distilled water, they were stained for $5 \mathrm{~min}$ in $5 \%$ Giemsa, washed in distilled water and mounted. Basophil granules appeared blue and acidophils dark pink.

iv) Ehrlich's triacid mixture. This mixture is composed of 12 parts of saturated Orange G aqueous solution, 8 parts of saturated acid fuchsin aqueous solution, 10 parts of saturated methyl green aqueous solution, 30 parts of distilled water, 18 parts of absolute ethanol and 5 parts of glycerine. Haemocytes were stained in this mixture for $15 \mathrm{~min}$, washed in distilled water and mounted. Basophilic granules appeared pale green, neutrophilic violet and acidophilic appeared coppery red.

v) Carbohydrate detection (Periodic AcidSchiff, PAS). A commercial Kit (Periodic Acid Schiff -PAS- Staining System, Sigma) was used and manufacturer instructions were followed. Positive sites appeared pink/red.

vi) Lipid detection (Sudan Black B staining). Haemocytes, fixed as above, were washed in PBS, treated for 3 min with $50 \%$ ethanol and immersed for $15 \mathrm{~min}$ in a saturated solution of Sudan Black B in 70\% ethanol. Slides were then immersed in 50\% ethanol, rinsed with distilled water and mounted. Black spot revealed the presence of lipids.

\section{Image analysis}

Light microscopic images were acquired by a system consisting of a colour video camera (JVC 3-CCD), a Leica DM-LB microscope (1000x magnification) and a PC provided with ImageNT and Microimage software developed by CASTI Imaging (Italy). Each assay was repeated in triplicate.
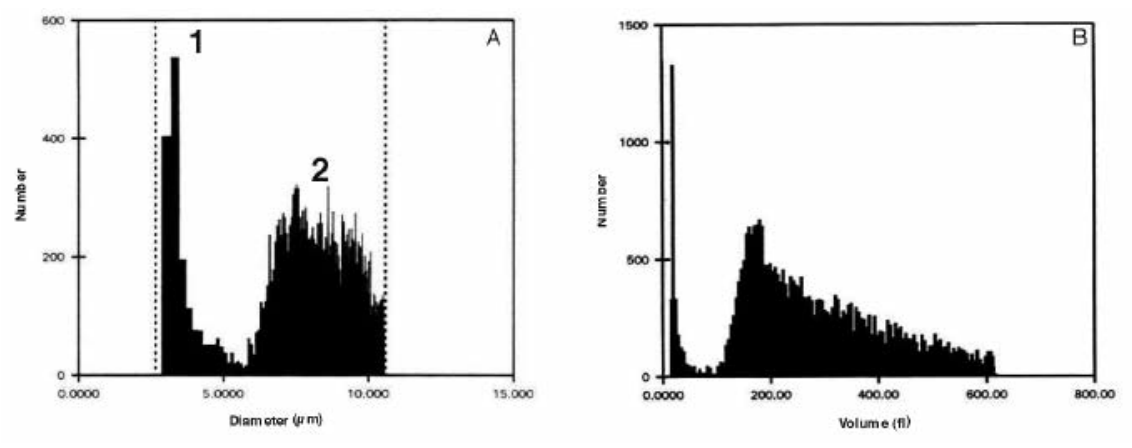

Figure 1. An example of haemocyte size frequency distribution in C. aestuarii. Haemocyte diameter (A), expressed in $\mu \mathrm{m}$, and haemocyte volume (B), expressed in femtolitres (fL).

\section{Results}

Analysis of haemocyte size frequency distribution revealed the presence of two main haemocyte fractions in the haemolymph of $C$. aestuarii, depending on cell size (Figure 1A, 1B). The first fraction was of about 3-5 $\mu \mathrm{m}$ in diameter and 30-50 fL in volume, the second was of about 6-12 $\mu \mathrm{m}$ in diameter and over 200 fL in volume. Mean cell diameter was $8.20 \pm 1.7$ $\mu \mathrm{m}$, whereas mean cell volume was $272.30 \pm 143.5 \mathrm{fL}(\mathrm{n}=10)$.

Three main haemocyte types were identified in the haemolymph of $C$. aestuarii by light microscopy. In in vivo observation, cells were classified on the basis of the presence/absence of cytoplasmic granules as granulocytes $(11.94 \pm 1.43 \mu \mathrm{m}$ in diameter; $\mathrm{n}=100)$, with a great number of refractile granules (Figure $2 \mathrm{~A})$, semigranulocytes $(12.38 \pm 1.76 \mu \mathrm{m}$; $\mathrm{n}=100$ ), containing a variable number of refractile granules (Figure 2B) and hyalinocytes $(7.88 \pm 1.6 \mu \mathrm{m} ; \mathrm{n}=100)$, without evident cytoplasmic granules (Figure 2C). In addition, a peculiar cell type (25-30 $\mu \mathrm{m}$ in diameter), defined as lipo-protein cell, was occasionally found (about 1\%) in haemolymph. It had a great vacuole and a peripheral cytoplasm with evident granules (Figure 2D).

After Giemsa staining, granulocytes (28\%) showed an oval, eccentric nucleus and abundant cytoplasmic granules (about 0.2-0.5 $\mu \mathrm{m}$ in diameter) (Figure $3 \mathrm{~A}$ ). Conversely, hyalino-cytes (44\%) had a large, central, round nucleus and did not contain granules appreciable under the light microscope (Figure 3B, 3C). Semigranulocytes $(27 \%)$ were an intermediate cell type between hyalinocytes and granulocytes: they showed an eccentric, spherical nucleus and had less granules than granulocytes (Figure 3A, 3C, 3D). Both granulocytes and hyalinocytes appeared as spherical cells (round haemocytes) or amoebocytes (spreading haemocytes), being able to emit pseudopodia. Granulocytes and semigranulocytes (but not hyalinocytes and lipoprotein cells) stained in vivo with Neutral Red 
dye, indicating that stained granules were lysosomes (Figure 3E, 3F).

Granule-containing cells (including semigranulocytes) were further divided into three different subpopulations: acidophils (64\%), basophils (35\%) and neutrophils (1\%) (Figure 4A-4F). Basophils had a blue (Pappenheim's staining) or pale green (Ehrlich's mixture) cytoplasm, acidophils showed a reddish-pink (Pappenheim) or coppery red (Ehrlich) cytoplasm, while neutrophils had a violet cytoplasm (Ehrlich). Hyalinocytes showed always a basophil cytoplasm.

In $C$. aestuarii, all haemocyte types were positive to the PAS reaction, revealing the presence of carbohydrates (Figure 5A-5C). However, carbohydrate distribution differed among cell types. In granulocytes (Figure 5A), carbohydrates diffused throughout the cytoplasm and inside granules, in hyalinocytes (Figure 5B) carbohydrates diffused throughout the cytoplasm, whereas in semigranulocytes (Figure 5C) PAS positivity was confined to the cytoplasm periphery and not in granules.

All cell types were positive to the Sudan Black B staining for lipids. Lipids were mainly detected on cell membranes, even if black spots were also observed in the cytoplasm of granulocytes (Figure 5D-5F).

\section{Discussion}

In spite of the efforts of some authors (see Bauchau, ${ }^{1}$ for example) to establish a convenient terminology for decapod haemocytes, their classification is still controversial. This is mainly due to differing criteria used to classify crustacean haemocytes. As a consequence, confusion in nomenclature arises and comparison of blood cells from differing crustacean species is often difficult.

In the present study, we examined under light microscope the circulating haemocytes from the crab $C$. aestuarii and proposed their classification on the basis of both morphological (i.e., presence/absence of cytoplasmic granules) and cytochemical features of cells. Analysis of haemocyte size frequency distribution, never performed in a crab species, revealed the presence of two distinct haemocyte fractions in $C$. aestuarii haemolymph. They ranged from 3-5 $\mu \mathrm{m}$ (the first) and from 6-12 $\mu \mathrm{m}$ (the second). The Coulter Counter analysis provided a general view of haemocyte populations and suggested that $C$. aestuarii haemocytes had a great variability in cell size. After this preliminary analysis, C. aestuarii haemocytes were examined under light microscope in order to distinguish cell types. Interestingly, cell size measured in unfixed haemocytes using the ImageNT and
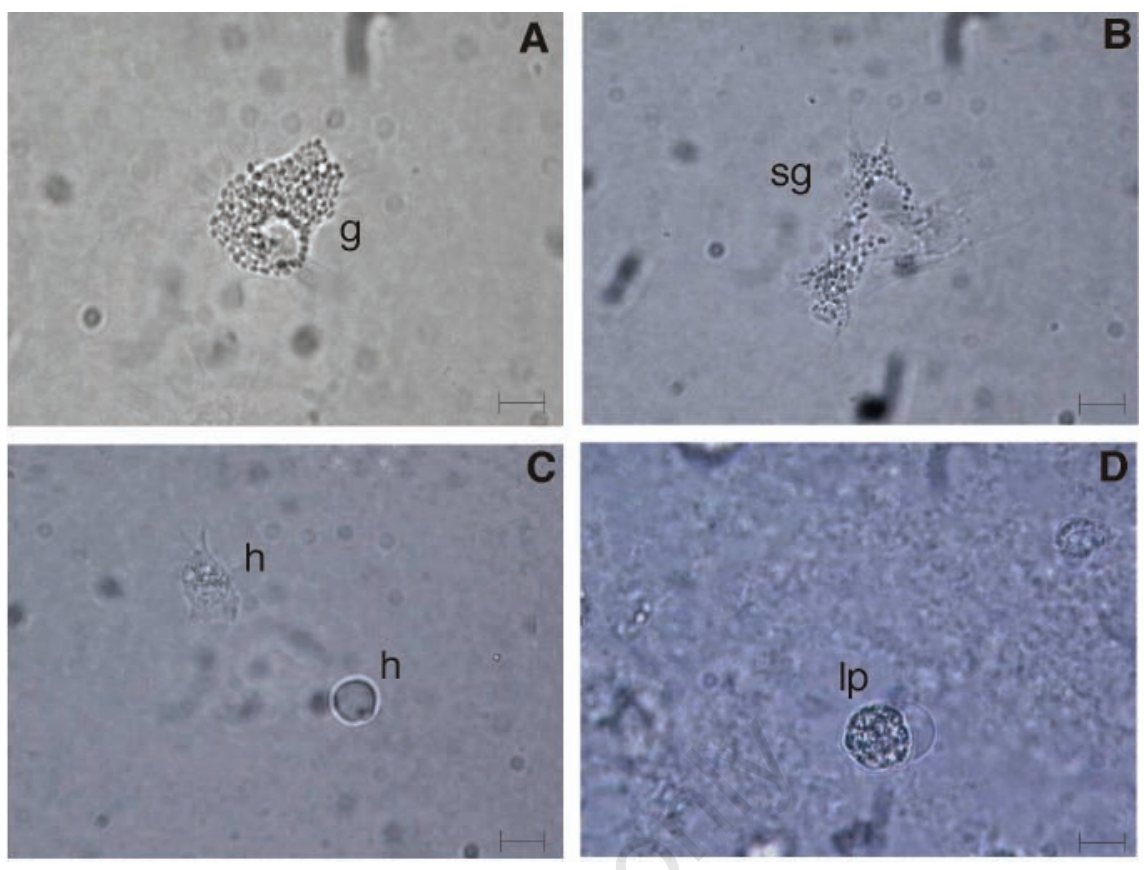

Figure 2. Unfixed haemocytes of $C$. aestuarii, observed in vivo (A-D). g: granulocyte; sg: semigranulocyte; h: hyalinocytes; lp: lipoprotein cell. Bar length: $5 \mu \mathrm{m}$.
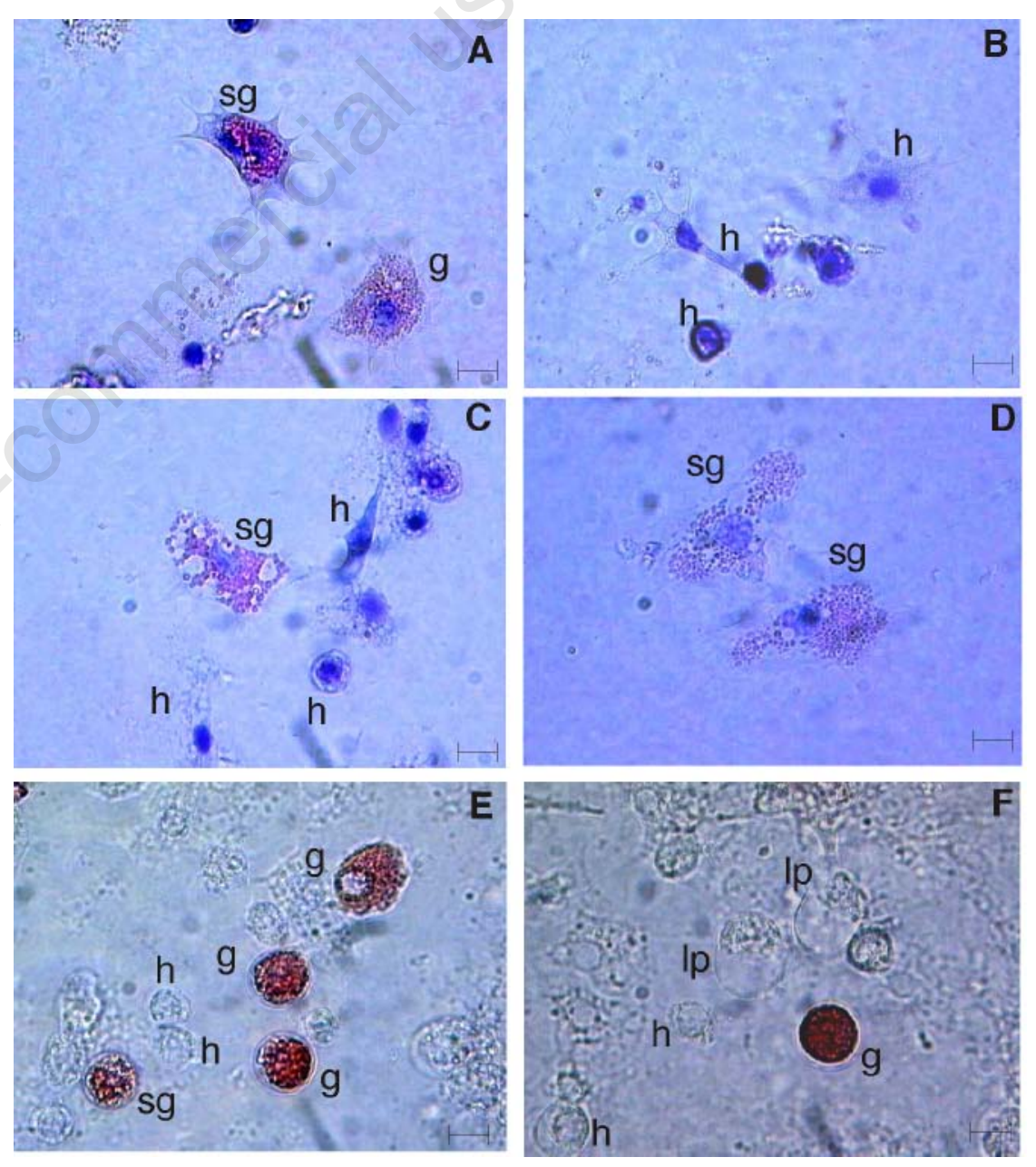

Figure 3. C. aestuarii haemocytes stained with Giemsa's dye (A-D) and vitally stained with Neutral Red, showing lysosomes (arrows) (E, F). g: granulocytes; sg: semigranulocytes; h: hyalinocytes; lp: lipoprotein cells. Bar length: $5 \mu \mathrm{m}$. 
Microimage software (granulocytes: $11.94 \pm 1.43 \mu \mathrm{m}$ in diameter; hyalinocytes: $7.88 \pm 1.6 \mu \mathrm{m}$; semigranulocytes: $12.38 \pm 1.76$ $\mu \mathrm{m})$ was almost similar to that recorded by the Coulter Counter. Indeed, two main fractions of haemocytes were detected under light microscope: the former of about 6-7 $\mu \mathrm{m}$, the latter of about 11-12 $\mu \mathrm{m}$. Following the morphological criterion proposed by Bauchau ${ }^{1}$ and Hose $e t$ $a l .{ }^{7}$ that is the presence/absence of refractile granules, three basic cell types were recognised in the present study: granulocytes, semigranulocytes and hyalinocytes. A similar classification was also adopted for haemocytes from other Crustacea species, such as Panulirus cygnus, Potamon fluviatilis and Liocarcinus depurator. ${ }^{23-25}$ Gargioni and Barracco $^{8}$ classified haemocytes from both the penaeid, Penaeus paulensis, and the two palaemonids, Macrobrachium acanthurus and $M$. rosenbergii, as hyaline haemocytes, small granule haemocytes (semigranulocytes, in the present study) and large granule haemocytes (granulocytes, in the present study). Likewise, after Wright-Giemsa staining and observation under the transmission electron microscope, circulating haemocytes from the Chinese prawn Fenneropenaeus chinensis were divided into hyaline haemocytes, small granular haemocytes and large granular haemocytes. ${ }^{26}$ Conversely, in Cancer pagurus, Vogan and Rowley ${ }^{27}$ identified four haemocyte types hyaline cells, eosinophil granulocytes, basophil granulocytes, eosinophil/basophil granulocytes - on the basis of nucleus morphology and dyeing characteristics of cytoplasm.

Although Hose $e t$ al. ${ }^{7}$ used the location of the nucleus (central or eccentric) as a factor to distinguish small granule haemocytes (semigranulocytes in the present study) from large granule haemocytes (granulocytes in the present study), we suggested that nucleus position is not an useful criterion to distinguish granule-containing cells in $C$. aestuarii. Indeed, in this crab species, granulocytes and semigranulocytes showed generally an eccentric nucleus. Hyalinocytes were morphologically different from granulocytes and semigranulocytes when examined under the light microscope. They were smaller than granule-containing cells, had a higher nucleus:cytoplasm ratio, a basophilic cytoplasm and did not contain evident granules. In the present study, both granulocytes and hyalinocytes of $C$. aestuarii showed round or amoeboid shape, haemocytes being able to emit pseudopodia. Round and spreading haemocytes were also observed in Penaeus japonicus, even if in granulocytes only. ${ }^{28}$ In $C$. aestuarii, granulocyte cytoplasm was packed with large, round, refractile granules, while semigranulocytes contained less granules than granulocytes. By means of both Pappenheim's panoptical staining and
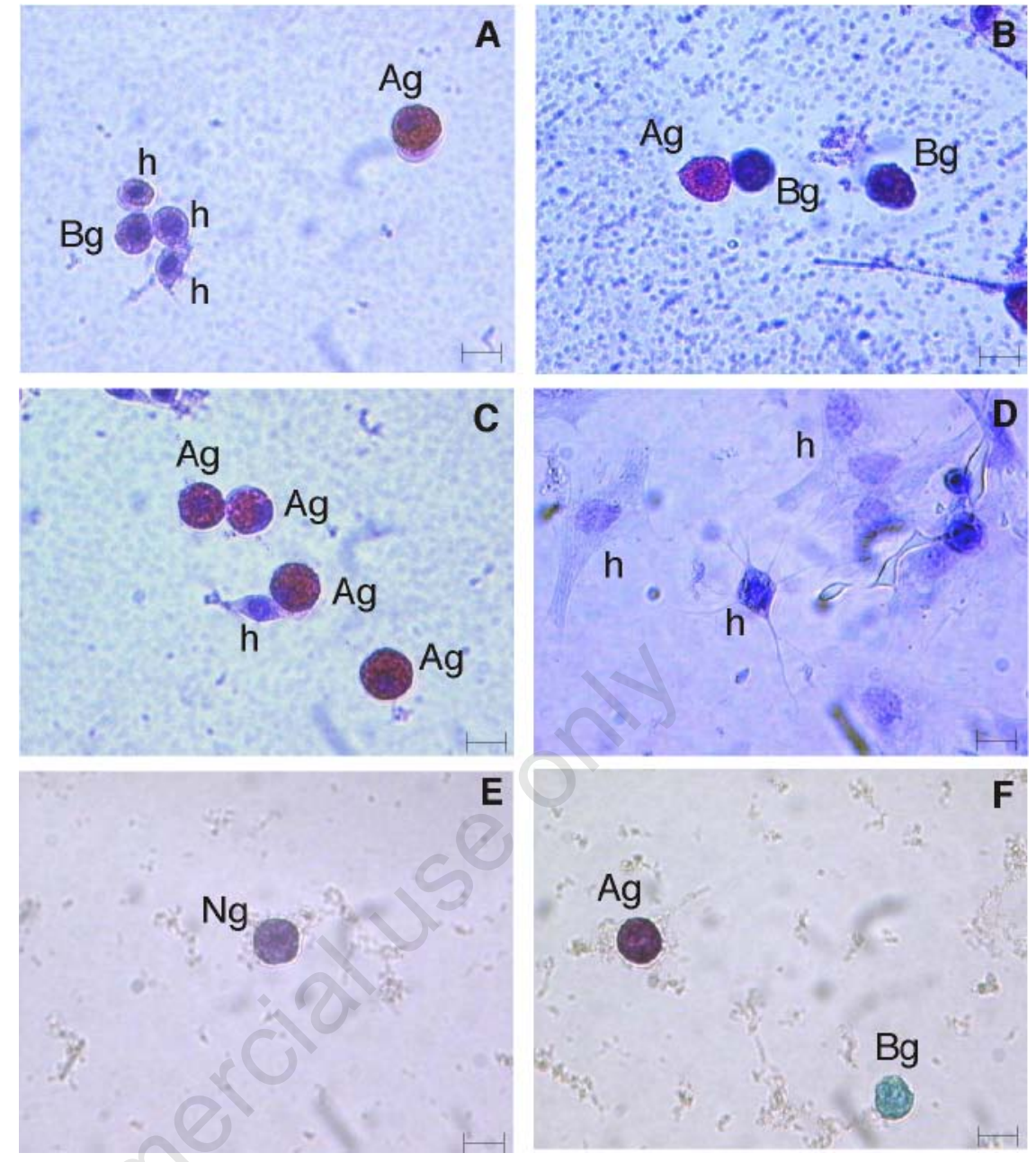

Figure 4. C. aestuarii haemocytes stained with Pappenheim's (A-D) and Ehrlich's triacid mixtures (E, F); h: hyalinocytes; Ag: acidophil granulocytes; Bg: basophil granulocytes; Ng: neutrophil granulocytes. Bar length: $5 \mu \mathrm{m}$.

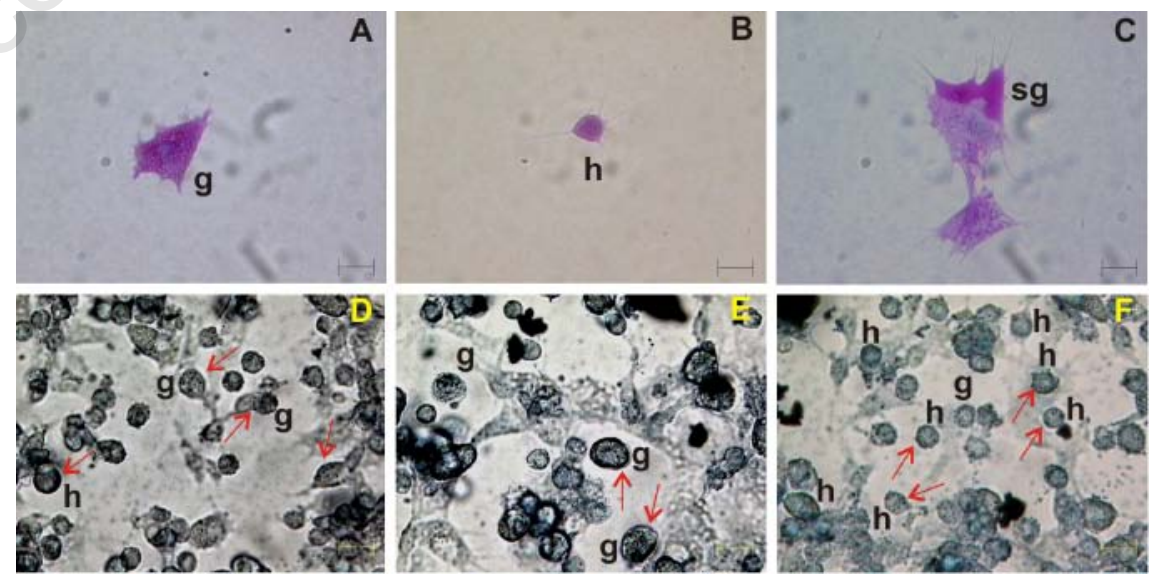

Figure 5. C. aestuarii haemocytes stained with PAS (A-C) and Sudan Black B (D-F). Red arrows indicate black deposits on cell membrane and in cytoplasm; g: granulocytes; sg: semigranulocytes; h: hyalinocytes. Bar length: $5 \mu \mathrm{m}$.

Ehrlich's triacid mixture, granule-containing cells (including semigranulocytes) of $C$. aestuarii were further divided into acidophilis (more than 65\%), basophils and neutrophils.
Interestingly, a peculiar cell type was occasionally found in haemolymph from $C$. aestuarii. It showed a great vacuole, a peripheral nucleus and a cytoplasm with evident gran- 
ules. We assume that it is not a true haemocyte, being rarely detectable in haemolymph. A similar cell type has previously been described by Sewell ${ }^{29}$ in haemolymph from the closely related species, $C$. maenas. In that study, the author named it "lipo-protein cell" and suggested that its presence in haemolymph was related to the moult stages of crabs (mainly at the $\mathrm{C} 4$ stage end), these cells being responsible for the secretion of the non-chitinous epicuticle prior to moulting. ${ }^{29}$ In order to confirm the hypothesis by Sewell, ${ }^{29}$ future studies will be performed in $C$. aestuarii to establish a relationship between crab moult stages and the presence of this peculiar cell type in haemolymph.

As for the abundance of each haemocyte type, high variability is generally reported in the literature for differing crustacean species. In the present study, granule-containing cells were the most abundant cell type. Conversely, in $M$. rosenbergii, hyalinocytes comprised $70 \%$ of total haemocytes and no semigranulocytes were found. ${ }^{30}$ In Sicyonia ingentis, $50-60 \%$ of the circulating haemocytes were hyalinocytes,${ }^{31}$ whereas semigranulocytes and granulocytes were $30 \%$ and $10 \%$ of the total, respectively. High percentages of hyalinocytes (5-8 times more abundant than granulocytes) were also observed in the crab Eriocheir sinensis, ${ }^{32}$ in the lobster Panulirus interruptus (about 56\% ${ }^{7}$ and in the crayfish Procambarus clarki (more than $70 \%) .{ }^{33}$ Conversely, in the lobster $H$. americanus and the crab Loxorhynchus grandis, semigranulocytes reached more than $60 \%$ of the total cell number. ${ }^{7}$ Although the significance of this marked variability in the relative proportions of each haemocyte type among crustacean species remains unclear, influences of moult cycle, diet, harvesting, diseases and environmental contaminants cannot be excluded.

All haemocytes types from $C$. aestuarii were PAS positive, indicating that they contained carbohydrates. However, carbohydrate distribution differed among cell types (see Results). Interestingly, a similar carbohydrate distribution was previously described by Gargioni and Barracco $^{8}$ for haemocytes from $P$. paulensis, $M$. acanthurus and $M$. rosenbergii. Conversely, William and Lut ${ }^{16}$ classified $C$. maenas haemocytes in two types, one with glycogen-containing granules and the other with non-glycogencontaining granules. Overall, the results of the present study confirm the important role of crab haemocytes in both synthesis and transport of carbohydrates. According to the hypothesis of Bauchau, ${ }^{1}$ we suggested that haemocytes from $C$. aestuarii can regulate haemolymph sugar levels, depending on need.

Sudan Black B staining demonstrated that all haemocyte types of $C$. aestuarii contained lipids. Black deposits were mainly observed on the cell membrane of both hyalinocytes and granule-containing cells. However, black deposits were also found in the cytoplasm of granulocytes. In $H$. americanus, $P$. interruptus, and $L$. grandis, only hyalinocytes were positive to Sudan Black B. ${ }^{7}$ In that study, granules of the hyaline cells from all the three decapod species did not accumulate the stain, although membranes around the larger granules in some hyalinocytes of $H$. americanus displayed intense staining. ${ }^{7}$ Conversely, granulocyte cytoplasm remained unstained by Sudan Black $\mathrm{B}$ and the nucleus was always visible. ${ }^{?}$

Although the present study is not aimed to discuss the hypothetical differentiation pathways of $C$. aestuarii haemocytes (see Bauchau ${ }^{1}$ for hypotheses on crustacean haemocyte differentiation), the morphological features of hyalinocytes from $C$. aestuarii (a central nucleus, a high nucleus:cytoplasm ratio, the absence of evident granules in cytoplasm) resembles those of undifferentiated stem cells. This aspect will be better evaluated in future studies by means of specific antibodies, such as anti-CD34 previously used to detect stem cells in bivalves. ${ }^{34}$

Summarising, light microscopy and cytochemical analyses performed in the present study allowed us to identify three main haemocyte types in haemolymph from the crab $C$. aestuarii. Although preliminary morphological investigation of haemocytes under light microscope is considered necessary by investigators, ultrastructural and functional studies are also needed to better distinguish crab cell types and clarify their role in immune responses. To this aim, future studies will be performed.

\section{References}

1. Bauchau AG. Crustaceans. In: Ratcliffe NA, Rowley AF (eds). Invertebrate Blood Cells, Vol 2. London: Academic Press 1981; pp 385-420.

2. Johansson MW, Keyser P, Sritunyalucksana K, Söderhäll K. Crustacean haemocyte and haemato-poiesis. Aquaculture 2000;191: 45-52.

3. Ghiretti-Magaldi A, Milanesi C, Tognon G. Hemopoiesis in Crustacea Decapoda: origin and evolution of hemocytes and cyanocytes of Carcinus maenas. Cell Differ 1977;6:167-86.

4. Martin GG, Hose JE, Choi M, et al. Organization of hematopoietic tissue in the intermolt lobster, Homarus americanus. J Morphol 1993;216:65-78.

5. Chaga 0, Lignell $M$, Söderhäll K. The haemopoietic cells of the freshwater crayfish, Pacifastacus leniusculus. Anim Biol
1995;4:59-70.

6. Van de Braak CBT, Botterblom MHA, Liu W, et al. The role of the haematopoietic tissue in haemocyte production and maturation of the black tiger shrimp (Penaeus monodon). Fish Shellfish Immunol 2002; 12:253-72.

7. Hose JE, Martin GG, Gerard AS. A decapod hemocyte classification scheme integrating morphology, cytochemistry, and function. Biol Bull 1990;178:33-45.

8. Gargioni R, Barracco MA. Hemocytes of the Palaemonids Macrobrachium rosenbergii and $M$. acanthurus, and of the Penaeid Penaeus paulensis. J Morphol 1998;236:209-21.

9. Cornick JW, Stewart JE. Lobster (Homarus americanus) hemocytes: Classification, differential counts, and associated agglutinin activity. J Invertebr Pathol 1978;31: 194-203.

10. Stang-Voss C. Ultrastructure of invertebrate hemocytes. V. Hemocytes of Astacus astacus (L.) (Crustacea). Z Zellforsch Mikrosk Anat 1971;122:68-75.

11. Toney ME Jr. Morphology of the blood cells of some Crustacea. Growth 19585;22:3550.

12. Bodammer JE. Cytological observations on the blood and hemopoietic tissue in the crab, Callinectes sapidus. Cell Tissue Res 1978;187:79-86.

13. Smith VJ, Ratcliffe NA. Host defense reactions of the shore crab, Carcinus maenas, in vitro. J Mar Biol Ass UK 1978;58:367-79.

14. Ravindranath MH. The hemocytes of an isopod Ligia exotica roux. J Morphol 1974; 144:11-22.

15. Johnston MA, Elder HY, Davies PS. Cytology of Carcinus haemocytes and their function in carbohydrate metabolism. Comp Biochem Physiol 1973;46A:569-74.

16. William AJ, Lutz PL. Blood cell types in Carcinus maenas and their physiological role. J Mar Biol Ass UK 1975;55:671-4.

17. Manjula PL, Rahman K, Abraham TJ. Haemocyte classification and differential counts in the Indian spiny lobster, Panulirus homarus (linneaus). J Aquacult Tropics 1997;12:113-21.

18. Clare AS, Lumb G. Identification of haemocytes and their role in clothing in the blue crab Callinectes sapidus. Mar Biol 1994; 118: 601-10.

19. Battison A, Cawthorn R, Horney B. Classification of Homarus americanus hemocytes and the use of differential hemocyte counts in lobsters infected with Aerococcus viridans var. homari (Gaffkemia). J Invertebr Pathol 2003;84: 177-97.

20. Söderhäll K, Smith VJ. Separation of the hemocyte populations of Carcinus maenas 
and other marine decapods and prophenoloxidase distribution. Dev Comp Immunol 1983;7:229-39.

21. Matozzo V, Rova G, Marin MG. Haemocytes of the cockle Cerastoderma glaucum: morphological characterisation and involvement in immune responses. Fish Shellfish Immunol 2007;23:732-46.

22. Ballarin L, Cima F, Sabbadin A. Phagocytosis in the colonial ascidian Botryllus schlosseri. Dev Comp Immunol 1994;18:467-81.

23. Jussila J, Jago J, Tsvetnenko E, Dunstan B, Evans L. Total and differential haemocyte counts in western rock lobster (Panulirus cygnus George) under post-harvest stress. Mar Freshwater Res 1997;48:863-67.

24. Yavuzcan H, Atar H. Haemocyte classification and differential counts in the freshwater crab, Potamon fluviatilis. Turk J Vet Anim Sci 2002;26:403-6.

25. Hammond JA., Smith VJ. Lipoplysaccha- ride induces DNA-Synthesis in a sub-population of hemocytes from the swimming crab, Liocarcinus depurator. Dev Comp Immunol 2002;26:227-36.

26. Zhang ZF, Shao M, Kang KH. Classification of haematopoietic cells and haemocytes in Chinese prawn Fenneropenaeus chinensis. Fish Shellfish Immunol 2006;21:15969.

27. Vogan C, Rowley AF. Effects of shell disease syndrome on the haemocytes and humoral defences of the edible crab, Cancer pagurus. Aquaculture 2002;205: 237-52.

28. Rodriguez J, Boulo V, Mialhe E, Bachere E. Characterisation of shrimp haemocytes and plasma components by monoclonal antibodies. J Cell Sci 1995;108:1043-50.

29. Sewell MT. Lipo-protein cells in the blood of Carcinus maenas, and their cycle of activity correlated with the moult. Quart J Microsc Sci 1955;96:73-83.
30. Vázquez L, Pérez A, Millán D, et al. Morphology of hemocytes from the freshwater prawn Macrobrachium rosenbergii. J Morphol 1997;234:147-53.

31. Hose JE, Martin GG. Defense functions of granulocytes in the ridgeback prawn Sicyonia ingentis. J Invert Pathol 1989;53: $335-46$.

32. Bauchau AG, Plaquet JC. Variation du nombre des hémocytes chez les Crustacés Brachyoures. Crustaceana 1973;24:215-23.

33. Lanz H, Tsutsumi V, Aréchiga H. Morphological and biochemical characterization of Procambarus clarki blood cells. Dev Comp Immunol 1993;17:389-97.

34. Cima F, Matozzo V, Marin MG, Ballarin L. Haemocytes of the clam Tapes philippinarum (Adams \& Reeve, 1850): morphofunctional characterisation. Fish Shellfish Immunol 2000;10:677-93. 